\title{
Pharmacological manipulation of vascular endothelium function in non-diabetic and streptozotocin-diabetic rats: effects on nerve conduction, hypoxic resistance and endoneurial capillarization
}

\author{
N. E.Cameron, M. A. Cotter, K. C. Dines, E.K.Maxfield \\ Department of Biomedical Sciences, University of Aberdeen, Scotland, UK
}

Summary. We examined the potential for some of the abnormalities of vascular endothelium found in diabetes mellitus to cause neuropathic changes. Non-diabetic rats were treated for 2 months with the cyclo-oxygenase inhibitor flurbiprofen $\left(5 \mathrm{mg} \cdot \mathrm{kg}^{-1} \cdot \mathrm{day}^{-1}\right)$ to reduce prostacyclin production, the nitric oxide synthase inhibitor $\mathrm{N}^{\mathrm{G}}$-nitro-L-arginine $(5$ or $25 \mathrm{mg} \cdot \mathrm{kg}^{-1} \cdot \mathrm{day}^{-1}$ ), or combined treatment. There were dosedependent reductions in sciatic motor and saphenous sensory conduction velocity. The two inhibitors acted synergistically, thus, the 5-6\% motor conduction deficits $(p<0.01)$ produced by either flurbiprofen or $\mathrm{N}^{\mathrm{G}}$-nitro-L-arginine (5 mg $\cdot \mathrm{kg}^{-1}$. day $\left.{ }^{-1}\right)$ increased to $17 \%(p<0.001)$ for combined treatment. With $\mathrm{N}^{\mathrm{a}}$-nitro-L-arginine $\left(25 \mathrm{mg} \cdot \mathrm{kg}^{-1} \cdot\right.$ day $\left.^{-1}\right)$ and flurbiprofen, motor and sensory conduction velocity were reduced by $23 \%(p<0.001)$ and $12 \%(p<0.001)$, respectively, matching the deficits following 2-month streptozotocin diabetes. $\mathrm{N}^{\mathrm{G}}$-nitro-L-arginine $\left(25 \mathrm{mg} \cdot \mathrm{kg}^{-1} \cdot \mathrm{day}^{-1}\right)$ and flurbiprofen together produced a $13 \%$ prolongation of the time taken for $80 \%$ hypoxic conduction failure in vitro $(p<0.05)$ and a $10 \%$ reduction in sciatic capillary density. A second in- vestigation tested an alternative hypothesis that overproduction of nitric oxide was responsible for vascular-related complications in diabetes, the prediction being that $\mathrm{N}^{\mathrm{G}}$-nitro-L-arginine $\left(5 \mathrm{mg} \cdot \mathrm{kg}^{-1} \cdot\right.$ day $\left.^{-1}\right)$ would prevent nerve dysfunction. However, rather than prophylaxis during 2-month streptozotocin diabetes, treatment exacerbated nerve abnormalities. Thus, $\mathrm{N}^{\mathrm{G}}$-nitro-L-arginine worsened $(8 \%, p<0.001)$ the motor conduction deficit, there was an $11 \%$ increase in hypoxic conduction failure time $(p<0.01)$ and an $11 \%$ reduction in endoneurial capillary density $(p<0.01)$. We conclude that overproduction of nitric oxide is unlikely to be involved in the aetiology of experimental diabetic neuropathy. However, endothelial dysfunction resulting in impaired nitric oxide and prostacyclin synthesis could make a substantial contribution.

Key words: Vascular endothelium, nitric oxide, prostacyclin, nerve conduction, neuropathy, ischaemic resistance, capillary density, vasa nervorum, diabetic rat.
Vascular factors may contribute to the aetiology of neuropathy in diabetes mellitus, exerting their action via impaired nerve blood flow and endoneurial hypoxia [1]. Evidence favouring this view includes measurement of endoneurial blood flow and oxygen tension in diabetic rats and patients [2-5], and parallels with some neurological abnormalities found for central hypoxaemia [6-8].

Dysfunction of vessels and vascular beds in diabetic animals and patients is well documented $[9,10]$; a broad range of abnormalities are found affecting both vascular smooth muscle and endothelium. Thus, reactivity to $\alpha$ adrenoceptor agonists is altered [11], voltage-dependent $\mathrm{Ca}^{2+}$ channel activity is enhanced [12], angiotensin converting enzyme levels are elevated [9], and ATP-sensitive $\mathrm{K}^{+}$channel mediated vasodilation is reduced $[10,13]$. For endothelium, major factors are diminished synthesis of prostacyclin and nitric oxide (NO) [10, 14-17], and in- creased levels of circulating endothelin [18]. Many of these findings have been made on isolated vascular tissues in vitro, although several are supported by in vivo investigations [16]. However, it is difficult to extrapolate from experiments which suggest generalised abnormalities of smooth muscle or endothelium to the performance of the whole cardiovascular system in conscious animals or to specific effects on vascular beds of organs susceptible to diabetic complications such as peripheral nerve.

The effects of diabetes on regional blood flow in conscious rats are complex. It is notable, though, that hindlimb blood flow is reduced and the effects of agents that modulate NO production are attenuated $[19,20]$. Given that prostacyclin synthesis by sciatic nerve epi/perineurial vessels is impaired by diabetes [15], that deficits in NO-mediated endothelium-dependent relaxation are prevented by aldose reductase inhibition [10], and that 
nerve conduction abnormalities are prevented by both aldose reductase inhibitors $[21,22]$ and evening primrose oil treatment (which supplies substrate for prostacyclin production) [23-25], the following hypothesis may be advanced. Endothelial abnormalities in diabetes reduce the synthesis of prostacyclin and NO, which decreases local blood flow and favours platelet aggregation; vascular effects that play a major role in the aetiology of peripheral nerve dysfunction in diabetes. To test the potential for causing nerve conduction abnormalities, non-diabetic rats were chronically treated with the cyclo-oxygenase inhibitor flurbiprofen to reduce prostacyclin synthesis, and the NO synthase inhibitor $\mathrm{N}^{\mathrm{G}}$-nitro-L-arginine (NOARG) [26], both alone and in combination.

Recently, Corbett et al. [27] suggested an hypothesis for vascular dysfunction that is diametrically opposed to the present proposition. Based on the idea that aminoguanidine, which prevents the development of neurological complications in experimental diabetes [28, 29], inhibited NO synthase, and that a conventional NO inhibitor prevented glucose-induced vascular changes in granulation tissue, it was argued that overproduction of NO occurs in diabetes. The potential resultant vasodilation would chronically increase capillary pressure. This would damage vascular beds in tissues prone to diabetic complications, causing deleterious functional changes. Thus, the hypothesis predicts that chronic NOARG treatment should prevent nerve dysfunction in diabetic rats, whereas the thesis presented above anticipates a worsening of function. These predictions were tested in a second study.

\section{Materials and methods}

\section{Animals and treatment}

Male Sprague-Dawley rats (Aberdeen University breeding colony), 19 weeks of age at the start of the study were used. For the first investigation, one group of rats was untreated for a further 2 months (agematched control group). Five other groups of rats were given different treatment regimens over 2 months. One group received the cyclo-oxygenase inhibitor flurbiprofen (Sigma, Poole, Dorset, UK) in the drinking water such that the effective dose was approximately $5 \mathrm{mg} \cdot \mathrm{kg}^{-1} \cdot$ day $^{-1}$. This dose was chosen as it was previously found to completely block the effects of $\omega-6$ essential fatty acid treatment in vivo for diabetic rats [25]. The dose approximately corresponds to that recommended for the treatment of rheumatoid arthritis in patients and, in animal experiments, substantially blocks cyclo-oxygenase-mediated prostanoid production in a variety of tissues both in vivo and in vitro [30]. Two other groups were treated with $\mathrm{N}^{\mathrm{G}}$-nitroL-arginine (Sigma) in the drinking water at doses of 5 and $25 \mathrm{mg} \cdot \mathrm{kg}^{-\mathrm{t}}$ - day ${ }^{-1}$, respectively. Preliminary experiments on two rats with chronically implanted carotid cannulae (under $2-5 \%$ halothane anaesthesia) were used to establish the oral availability of NOARG. Mean systemic blood pressure was monitored over 2 days prior to the start of NOARG treatment and for 2 days after, using the $5 \mathrm{mg} \cdot \mathrm{kg}^{-1} \cdot \mathrm{day}^{-1}$ dose. Rats were conscious and unrestrained, the cannula was connected to a pressure transducer, tubing being guarded by a flexible stainless steel sheath. The average resting blood pressure was $117.5 \mathrm{~mm} \mathrm{Hg}$ before treatment, and this was increased to $136.3 \mathrm{~mm} \mathrm{Hg}$ with $5 \mathrm{mg} \cdot \mathrm{kg}^{-1}$. day ${ }^{-1}$ NOARG. Measurements were not made for the $25 \mathrm{mg} \cdot \mathrm{kg}^{-1}$. day ${ }^{-1}$ dose, partly for technical reasons related to maintaining the patency of the cannulae, but also because of signs of physiological stress in a pilot study where rats were introduced directly to full treatment. Thus, for these ex- perimental animals, treatment was introduced gradually over a 5day period starting from half the intended dose. Two further groups of rats were given flurbiprofen $\left(5 \mathrm{mg} \cdot \mathrm{kg}^{-1} \cdot\right.$ day $\left.^{-1}\right)$ in combination with NOARG ( 5 or $25 \mathrm{mg} \cdot \mathrm{kg}^{-1} \cdot$ day $^{-1}$ ); again, for the high NOARG dose, treatment was gradually introduced over 5 days.

For the second investigation, rats were made diabetic with streptozotocin (Sigma) (40 mg $\cdot \mathrm{kg}^{-1}$ in $20 \mathrm{mmol} \cdot \mathrm{l}^{-1}$ sodium citrate buffer, $\mathrm{pH} 4.5$, i.p.). Diabetes was verified $24 \mathrm{~h}$ later by estimating hyperglycaemia and glycosuria (Visidex II and Diastix; Ames, Slough, Bucks., UK). Final plasma glucose levels were determined using a standard test kit (GOD-Perid method; Boehringer Mannheim, Mannheim, FRG) on samples taken on the day of the experiments. Diabetic rats were divided into two groups; one was untreated for 2 months and acted as a control group, whereas the other group was treated with $5 \mathrm{mg} \cdot \mathrm{kg}^{-1} \cdot$ day-i NOARG for 2 months.

\section{Nerve conduction velocity}

In final experiments (1-1.5 g $\mathrm{kg}^{-1}$ urethane anaesthesia i. p.), nerve conduction velocity $(\mathrm{NCV})$ was measured in vivo between the sciatic notch and the knee for nerve branches supplying tibialis anterior (peroneal division) and gastrocnemius (tibial division) muscles; an average value for these branches was taken as representative of sciatic motor NCV [3]. Sensory NCV was measured in the saphenous nerve between the groin and ankle. Rectal and nerve temperatures were monitored, and regulated between 36.5 and $37.5^{\circ} \mathrm{C}$. Methods have previously been described in detail [21].

\section{Sciatic nerve resistance to hypoxia in vitro}

The sciatic nerve trunk was removed between the sciatic notch and its bifurcation at the knee. It was mounted on bipolar stimulating (proximal end) and recording electrodes (distal end) in a chamber at $35-36^{\circ} \mathrm{C}$. It contained Krebs' solution with $5.5 \mathrm{mmol} \cdot \mathrm{I}^{-1}$ glucose for nerves from non-diabetic rats and $40 \mathrm{mmol} \cdot \mathrm{l}^{-1}$ glucose for nerves from diabetic rats. The bathing fluid was gassed with $95 \% \mathrm{O}_{2} / 5 \%$ $\mathrm{CO}_{2}$. Nerves were equilibrated for $30 \mathrm{~min}$, then the chamber was refilled with mineral oil pre-gassed with $100 \% \mathrm{~N}_{2}$. Nerves were stimulated with just supramaximal pulses ( $1 \mathrm{~Hz}, 0.05 \mathrm{~ms}$ width, $10 \mathrm{~mA}$ ), and compound action potential amplitude was monitored at 2-min intervals until it fell below $10 \%$ of its initial value. Methods have previously been described in detail [23].

\section{Sciatic nerve capillary density}

At the end of the experiment, rats were killed by exsanguination. The sciatic nerve trunk, between the sciatic notch and its bifurcation at the knee, was removed and divided into 5 equal length pieces which were mounted together, along with soleus and tibialis anterior muscle which also acted as support tissue. Samples were frozen in isopentane prechilled in liquid nitrogen. Sections of $10 \mu \mathrm{m}$ were cut on a cryostat, and capillary endothelium was stained for alkaline phosphatase [31]. Three sections, each $90 \mu \mathrm{m}$ apart, were taken and all capillaries in all nerve fascicles were counted with the aid of a projection microscope. Fascicle outlines were traced and their areas measured using a digitizing pad linked to a microcomputer. Thus, the measurements represent average capillary density for repeated sampling between sciatic notch and knee, on a fascicular area of approximately $10 \mathrm{~mm}^{2}$ for each nerve.

\section{Statistical analysis}

Results are expressed as group means \pm SEM. Data were subjected to one-way analysis of variance, and any statistically significant differences $(p<0.05)$ were assigned to individual between group comparisons using the Student's $t$-test, applying the Bonferroni correc- 

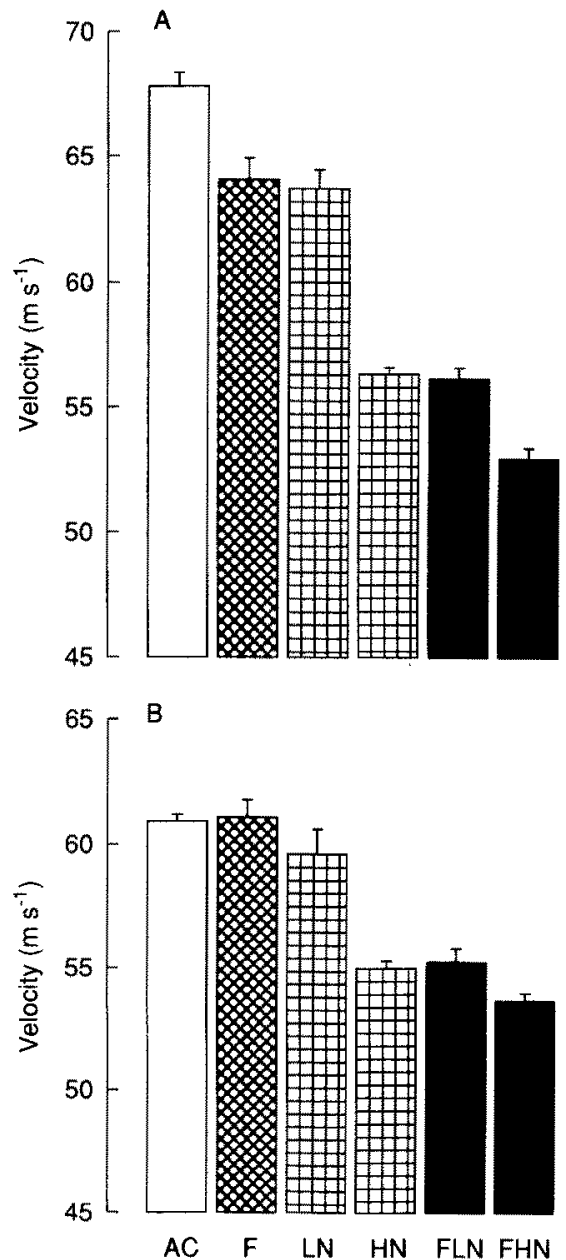

Fig. 1(A,B). Sciatic nerve motor (A) and saphenous sensory (B) conduction velocity in non-diabetic rats treated with flurbiprofen and $\mathrm{N}^{G}$-nitro-L-arginine (NOARG). AC, age-matched control group, $n=10 ; \mathrm{F}$, flurbiprofen-treated $\left(5 \mathrm{mg} \cdot \mathrm{kg}^{-1}\right.$. day $\left.{ }^{-1}\right)$ group, $n=10 ; \mathrm{LN}$, low-dose $\left(5 \mathrm{mg} \cdot \mathrm{kg}^{-1} \cdot\right.$ day $\left.^{-1}\right)$ NOARG-treated group, $n=10 ; \mathrm{HN}$, high-dose $\left(25 \mathrm{mg} \cdot \mathrm{kg}^{-1} \cdot \mathrm{day}^{-1}\right)$ NOARG-treated group, $n=10 ; \mathrm{FLN}$, flurbiprofen and low-dose NOARG-treated group, $n=14 ;$ FHN, flurbiprofen and high-dose NOARG-treated group, $n=14$. Error bars are SEM

tion when multiple comparisons were made (Instat; GraphPad, San Diego, Calif., USA).

\section{Results}

Investigation 1: effects of flurbiprofen and $N^{\mathrm{G}}$-nitro-L-arginine (NOARG) treatment on nerve function in non-diabetic rats

Plasma glucose levels were in the range $6.9 \pm 0.3$ to $8.3 \pm$ $0.2 \mathrm{mmol} \cdot 1^{-1}$. Body weight increased in all groups over the 2-month period, from a starting weight in the range $456 \pm 17 \mathrm{~g}$ to $499 \pm 15 \mathrm{~g}$. Weight increases were approximately $13 \%$ in age-matched control, low-dose NOARGtreated $\left(5 \mathrm{mg} \cdot \mathrm{kg}^{-1} \cdot \mathrm{day}^{-1}\right)$ and flurbiprofen-treated groups with and without low-dose NOARG treatment. The two groups treated with high-dose NOARG ( $25 \mathrm{mg}$. $\mathrm{kg}^{-1} \cdot$ day $^{-1}$ ) had a lesser weight gain of around $6 \%$.
Data for motor and sensory NCV are shown in Figure $1 \mathrm{~A}$ and $1 \mathrm{~B}$ respectively. Flurbiprofen or low-dose NOARG treatment produced small but significant reductions in motor NCV $(5.5 \%, p<0.01 ; 6.0 \%, p<0.001$, respectively) compared with the age-matched control value of $67.8 \pm 0.6 \mathrm{~m} \cdot \mathrm{s}^{-1}$. However, there was no significant effect on sensory NCV, which was $60.9 \pm 0.3 \mathrm{~m} \cdot \mathrm{s}^{-1}$ in agematched controls. High-dose NOARG treatment caused a greater reduction in motor NCV $(16.9 \%, p<0.001)$ and a significant diminution of sensory NCV $(9.8 \%, p<0.001)$ compared with age-matched controls. These effects were also greater than with low-dose NOARG treatment $(p<0.001$ for both motor and sensory NCV). Combined treatment with flurbiprofen and low-dose NOARG caused motor and sensory NCV deficits approximately equivalent to high-dose NOARG treatment alone $(17.2 \%$, motor; $9.3 \%$, sensory; both $p<0.001$ compared

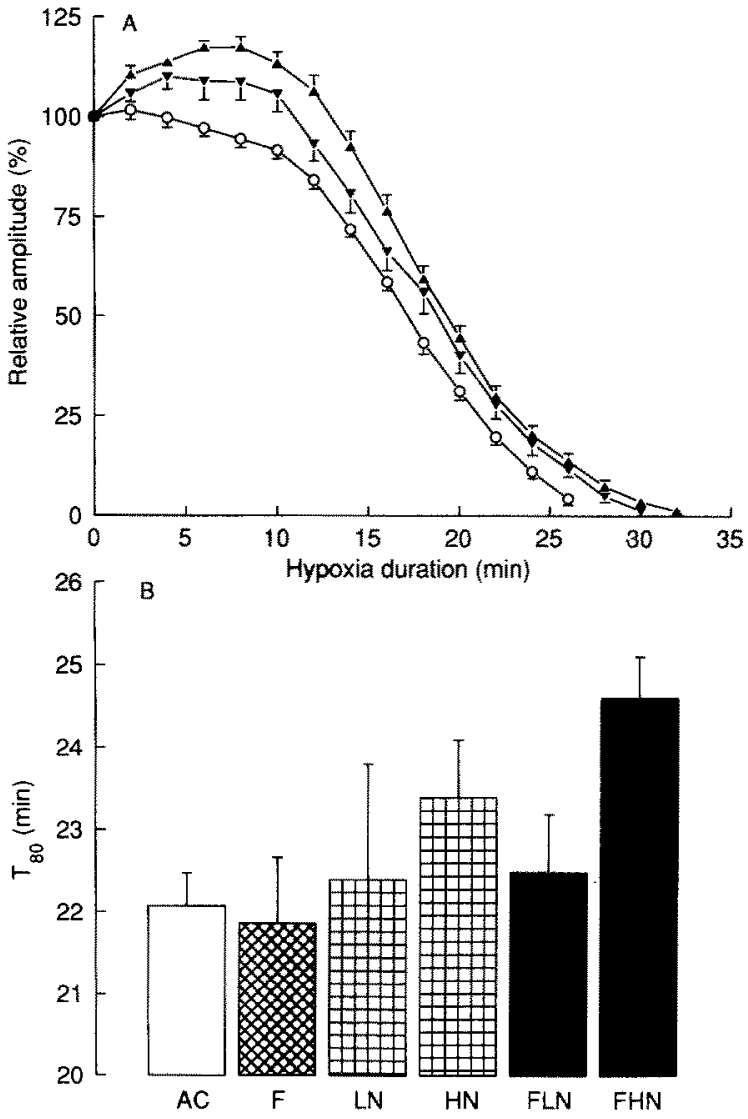

Fig. 2(A,B). Sciatic nerve resistance to hypoxia in vitro in nondiabetic rats treated with flurbiprofen and $\mathrm{N}^{\mathrm{a}}$-nitro-Larginine (NOARG). A, relative compound action potential amplitude is plotted against hypoxia duration. Age-matched control group (O), $n=10$; high-dose $\left(25 \mathrm{mg} \cdot \mathrm{kg}^{-1} \cdot\right.$ day $\left.^{-1}\right)$ NOARG-treated group $(\boldsymbol{\nabla}), n=10 ;$ flurbiprofen $\left(5 \mathrm{mg} \cdot \mathrm{kg}^{-1} \cdot\right.$ day $\left.^{-1}\right)$ and high-dose NOARG-treated group $(\mathbf{A}), n=14 . \mathbf{B}$, durations of hypoxia necessary for an $80 \%$ reduction in compound action potential amplitude $\left(\mathbf{T}_{80}\right)$. AC, age-matched control group, $n=10 ; \mathrm{F}$, flurbiprofentreated $\left(5 \mathrm{mg} \cdot \mathrm{kg}^{-1} \cdot\right.$ day $\left.^{-1}\right)$ group, $n=10 ; \mathrm{LN}$, low-dose $\left(5 \mathrm{mg} \cdot \mathrm{kg}^{-1}\right.$. day $^{-1}$ ) NOARG-treated group, $n=10 ; \mathrm{HN}$, high-dose $(25 \mathrm{mg}$. $\mathrm{kg}^{-1} \cdot$ day $^{-1}$ ) NOARG-treated group, $n=10$; FLN, flurbiprofen and low-dose NOARG-treated group, $n=14$; FHN, flurbiprofen and high-dose NOARG-treated group, $n=14$. Error bars are SEM 
Table 1. Endoneurial capillary density for non-diabetic rats treated with flurbiprofen and $\mathrm{N}^{\mathrm{G}}$-nitro-L-arginine for 2 months

\begin{tabular}{lll}
\hline Group & $n$ & $\begin{array}{l}\text { Density } \\
\left(\mathrm{mm}^{-2}\right)\end{array}$ \\
\hline Control & 10 & $59.8 \pm 0.5$ \\
Flurbiprofen-treated & 10 & $55.5 \pm 2.6$ \\
Low-dose NOARG-treated & 10 & $55.6 \pm 3.5$ \\
High-dose NOARG-treated & 10 & $53.8 \pm 1.0^{\mathrm{a}}$ \\
Flurbiprofen + low-dose NOARG-treated & 14 & $54.7 \pm 1.0$ \\
Flurbiprofen + high-dose NOARG-treated & 14 & $53.6 \pm 1.2^{\mathrm{a}}$ \\
\hline
\end{tabular}

NOARG, $\mathrm{N}^{G}$-nitro-L-arginine; low-dose $5 \mathrm{mg} \cdot \mathrm{kg}^{-1} \cdot$ day $^{-1}$; high-dose $25 \mathrm{mg} \cdot \mathrm{kg}^{-1} \cdot$ day $^{-1} \cdot{ }^{\mathrm{a}} p<0.05$ compared to the control group. Data are group means $\pm S E M$

Table 2. Sciatic motor and saphenous sensory conduction velocity and sciatic endoneurial capillary density for 2-month diabetic rats without and with $5 \mathrm{mg} \cdot \mathrm{kg}^{-1} \cdot \mathrm{day}^{-1} \mathrm{~N}^{\mathrm{G}}$-nitro-L-arginine treatment

\begin{tabular}{|c|c|c|c|c|}
\hline \multirow[t]{2}{*}{ Group } & \multirow[t]{2}{*}{$n$} & \multicolumn{2}{|c|}{$\begin{array}{l}\text { Conduction velocity } \\
\left(\mathrm{m} \cdot \mathrm{s}^{-1}\right)\end{array}$} & \multirow[t]{2}{*}{$\begin{array}{l}\text { Density } \\
\left(\mathrm{mm}^{-2}\right)\end{array}$} \\
\hline & & motor & sensory & \\
\hline Diabetic & 12 & $52.5 \pm 1.0$ & $52.5 \pm 1.2$ & $58.5 \pm 1.7$ \\
\hline
\end{tabular}

NOARG, $\mathrm{N}^{\mathrm{G}}$-nitro-L-arginine. ${ }^{\mathrm{a}} p<0.001,{ }^{\mathrm{b}} p<0.01$ compared to diabetic group. Data are group means \pm SEM

with the age-matched control group). The lowest values for NCV were found for combined flurbiprofen and highdose NOARG treatment, the deficits being $21.9 \%$ and $11.9 \%$ for motor and sensory nerves, respectively $(p<0.001)$. These were significantly greater than for highdose NOARG alone for motor $(p<0.01)$ but not for sensory NCV.

Curves illustrating the decline in sciatic nerve compound action potential amplitude with hypoxia duration in vitro for some of the groups are shown in Figure $2 \mathrm{~A}$. There were no significant differences between data for age-matched control and flurbiprofen or lowdose NOARG-treated groups (curves not shown). However, low-dose NOARG with flurbiprofen (data not shown) and high-dose NOARG treatments resulted in very similar curves that showed a significantly greater early hyperexcitability phase [32] $(p<0.05$ from 2 to $10 \mathrm{~min}$ for flurbiprofen and low-dose NOARG and from 4 to $10 \mathrm{~min}$ for high-dose NOARG). There was also a tendency for these curves to be shifted to the right compared to age-matched controls, which was significant $(p<0.05)$ from $26 \mathrm{~min}$ onward. For the high-dose NOARG and flurbiprofen-treated group, both the hyperexcitability and the shift to the right were enhanced such that all data points from $2 \mathrm{~min}$ onward were significantly different $(p<0.05)$ from the control group.

Figure 2B summarizes the durations of hypoxia necessary for $80 \%$ reductions in compound action potential amplitude $\left(\mathrm{T}_{80}\right)$ for all groups. Flurbiprofen and lowdose NOARG, both alone and in combination, had no significant effect on $T_{80}$ compared with the age-matched control group. With high-dose NOARG alone, $\mathrm{T}_{80}$ increased by $6.3 \%$ which was not statistically significant but, in combination with flurbiprofen, the increase was $12 \%$ $(p<0.05)$.
Table 1 shows endoneurial capillary density for all groups. Compared to control rats capillarization tended to be decreased in all treatment groups. However, this was only statistically significant $(p<0.05)$ for the approximately $10 \%$ reductions found with high-dose NOARG treatment, alone and combined with flurbiprofen.

\section{Investigation 2: effects of $N^{G}$-nitro-L-arginine (NOARG) treatment on nerve function in streptozotocin-diabetic rats}

Diabetes caused a $22.5 \%$ decrease in body weight over 2 months which was unaffected by low-dose NOARG $\left(5 \mathrm{mg} \cdot \mathrm{kg}^{-1} \cdot \mathrm{day}^{-1}\right)$ treatment. Plasma glucose concentrations for untreated and treated diabetic groups were $37.9 \pm 2.6$ and $38.9 \pm 1.6 \mathrm{mmol} \cdot 1^{-1}$, respectively.

Table 2 shows motor and sensory NCV data and endoneurial capillary density. NOARG treatment caused a $7.8 \%$ motor NCV reduction $(p<0.001)$, and a $5.1 \%$ deficit in sensory NCV that was not statistically significant. NOARG treatment also resulted in an $11.5 \%$ reduction $(p<0.01)$ in sciatic capillary density compared to the untreated diabetic group.

Figure 3 illustrates hypoxic resistance curves for the untreated and NOARG-treated diabetic groups. The latter showed a greater initial hyperexcitability and was also shifted to the right $(p<0.01$ for all points from 2 to $42 \mathrm{~min})$ indicating greater hypoxic resistance. $\mathrm{T}_{80}$ (Fig. 3 , inset) was $31.1 \pm 0.7 \mathrm{~min}$ for untreated diabetes, which was $11.3 \%$ increased by NOARG treatment $(p<0.01)$.

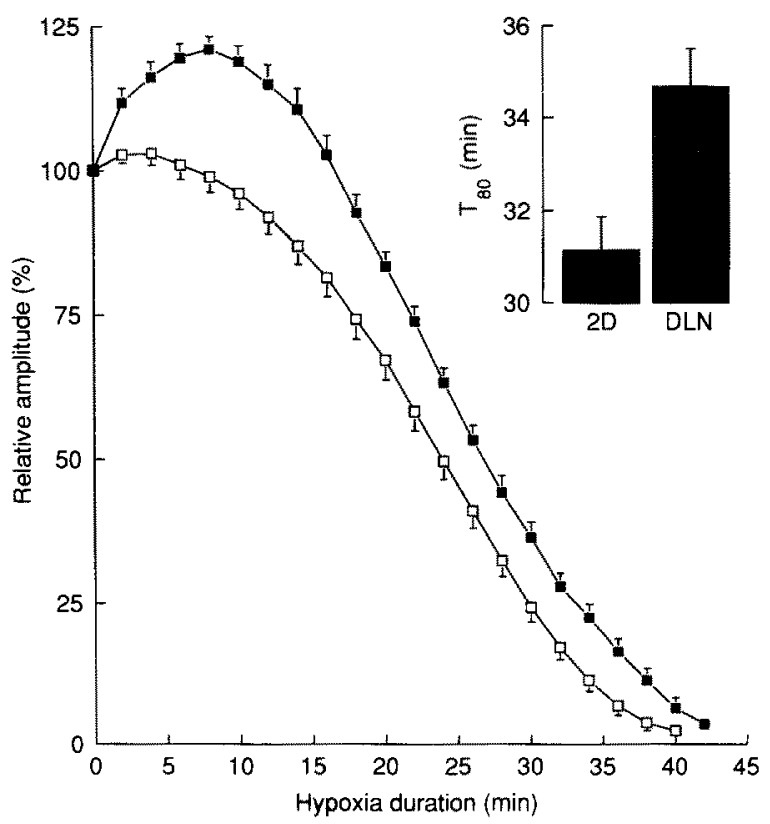

Fig.3. Effects of $\mathrm{N}^{\mathrm{G}}$-nitro-L-arginine (NOARG) treatment $\left(5 \mathrm{mg} \cdot \mathrm{kg}^{-1} \cdot \mathrm{day}^{-1}\right)$ on nerve hypoxic resistance in diabetic rats. Sciatic nerve relative compound action potential amplitude plotted against hypoxia duration for 2 -month diabetes without $(\square), n=12$, or with (घ),n=13, NOARG treatment. Inset graph, durations of hypoxia necessary for an $80 \%$ reduction in compound action potential amplitude $\left(\mathrm{T}_{80}\right)$. 2D, 2-month untreated diabetic group; DLN, 2-month NOARG-treated diabetic group. Error bars are SEM 


\section{Discussion}

The data demonstrate that creation of endothelium dysfunction in non-diabetic rats, by pharmacological blockade of local vasodilator production, causes NCV deficits similar to those found in experimental diabetes. A test of the converse notion, that over-production of NO in diabetic rats [27] could account for neuropathic abnormalities, showed that this was highly improbable. Thus, partial inhibition of NO synthesis led to further functional impairment.

Flurbiprofen or low-dose NOARG treatments alone caused very modest NCV changes in non-diabetic rats but their combined effects were more than additive, which may be viewed in terms of inhibition of two mutually compensatory mechanisms [33]. Thus, addition of flurbiprofen to low-dose NOARG had similar consequences to a five-fold increase in NOARG. It is plausible that endothelial dysfunction of prostacyclin and NO synthesis contribute synergistically to the aetiology of diabetic neuropathy. Numerous studies have identified reduced endothelium-dependent relaxation in vessels and vascular beds from diabetic animals and patients $[10,15-17,19$, $20,34,35]$. In aortas from diabetic rats an NO synthesis deficit was prevented by aldose reductase inhibition [10], which also improves nerve function [21]. Reduced prostacyclin production or sensitivity with diabetes has been noted in several tissues including sciatic vascular supply $[14,15,36]$. There, the abnormality arises from a lack of substrate as sciatic peri/epineurial vessels from diabetic rats synthesised prostacyclin at a greater rate than controls when supplied with arachidonic acid in vitro [15]. Evening primrose oil treatment increases plasma arachidonic acid concentration, which would promote prostacyclin production, and nerve function is improved [23]. The argument for the importance of prostanoid synthesis deficits in neuropathy is supported by the findings that the action of evening primrose oil in diabetic rats is completely blocked by flurbiprofen [25], and that nerve function is also restored by a prostacyclin analogue [37].

Whilst treatment with flurbiprofen and high-dose NOARG for 2 months caused NCV deficits similar to those seen with the same duration of untreated diabetes, effects on hypoxic resistance were more modest. Thus, $\mathrm{T}_{80}$ values $(24.6 \pm 0.5 \mathrm{~min})$ resemble those noted in a previous investigation [38] for 1 -month diabetes $(24.8 \pm 0.9 \mathrm{~min})$. Hypoxic resistance and NCV deficits in diabetes follow different time courses, the former progressively increases over the first 3 months of diabetes, whereas major changes in the latter occur within the first 2-4 weeks of diabetes $[21,38]$. Thus, treatment of non-diabetic rats with flurbiprofen and high-dose NOARG for 2 months was equivalent to 1 -month diabetes when all measures of nerve function examined are considered. It is, therefore, plausible that endothelium dysfunction could substantially contribute to diabetic neuropathy, although the failure to completely mimic diabetic neuropathic effects also suggests the involvement of other factors. These could include direct effects on nerve metabolism, for example, because of polyol pathway activity [39-41] or increased glucose availability [42]. However, NCV deficits and resistance to ischaemia also occur in experimental hypoxic neuropathy, where blood glucose levels are unaffected [6], thus, it is plausible that the other factors are primarily vascular in origin. These would include increased sympathetic tone and elevated $\alpha$-adrenoceptor sensitivity [11], increased vasoconstriction related to the renin-angiotensin system [9], and changes in vascular smooth muscle $\mathrm{Ca}^{2+}$ channel activity [12], since blockers of all these actions improve nerve function in diabetic rats $[3,38,41,43-45]$.

A further contribution to endoneurial hypoxia in diabetes could come from increased blood viscosity, impaired fibrinolysis, reduced erythrocyte deformability, and decreased oxygen unloading from haemoglobin [46, 47]. It is questionable whether the latter three parameters would be changed by flurbiprofen-NOARG treatment in non-diabetic rats; however, viscosity may be increased by platelet aggregation [33]. Thus, a wider range of rheological factors may exacerbate nerve abnormalities in diabetic rats, compared with rats in which endothelium dysfunction is pharmacologically induced.

The effect of chronic NO inhibition on regional blood flow has been examined in conscious rats [48]. Over $9 \mathrm{~h}$, hind-limb flow was $36 \%$ reduced by a dose of approximately $75 \mathrm{mg} \cdot \mathrm{kg}^{-1} \cdot$ day $^{-1}$ of $\mathrm{N}^{\mathrm{G}}$-nitro-L-arginine methyl ester (which has a similar potency to NOARG). The hindlimb supply is responsible for sciatic nerve perfusion, therefore, it is likely that there was a similar magnitude of flow reduction in this study. In diabetic rats, sciatic endoneurial blood flow is $40 \%$ reduced compared with nondiabetic rats $[3,49]$. Thus, given their synergistic action, $25 \mathrm{mg} \cdot \mathrm{kg}^{-1} \cdot$ day $^{-1}$ NOARG plus flurbiprofen treatment might be expected to cause NCV deficits similar to those for diabetes if a major determinant was the reduction in perfusion, which is supported by the data in this investigation.

Chronic low-dose NOARG treatment produced an approximately two-fold greater impairment of the already compromised nerve function in diabetic rats than was apparent for the same dose in non-diabetic rats. Greater sensitivity to an inhibitor might be predicted if NO production or action was already diminished in diabetic rats, as has been suggested from in vitro and in vivo studies $[9,10$, 50]. The data also fit in with expectations from investigations of acute NO inhibitor administration on hind-limb blood flow in conscious diabetic rats, which provide evidence of impaired basal and stimulated NO synthesis [19, 20]. This effect may have parallels in diabetic patients where deficits in NO production have been demonstrated [16] and neuropathy is exacerbated by vascular insufficiency [51].

The data for capillary density showed that there was no significant effect of flurbiprofen or NOARG treatment in non-diabetic rats except for the two groups subjected to the highest degree of blockade, despite the likelihood of reduced vasa nervorum blood flow for all treatments [15, 19]. Several previous studies have also demonstrated that capillary density is not decreased by untreated diabetes $[23,38,41,44]$, despite a $40 \%$ decline in blood flow [3]. However, in the low-dose NOARG-treated diabetic rats there was regression of the capillary bed. Experiments using several vasodilator treatments $[23,37,38,41,45] \mathrm{re}$ - 
vealed vasa nervorum angiogenesis in diabetic rats, whereas for treated non-diabetic rats angiogenesis was not found despite increases in capillary size and patency $[37,38,52]$. This difference was attributed either to increases in blood flow in diabetic rats of sufficient magnitude to be suprathreshold for mechanical stimulation of angiogenesis [53], or to the presence of circulating proliferative factors [38]. Taken together with data for NOARG treatment, however, the evidence leads to the general conclusion that the endoneurial vascular bed in diabetic rats shows greater susceptibility to manipulations likely to produce further changes in blood flow in either direction than is the case for non-diabetic rats. The reason for this is elusive, but if the argument also applies to patients, the need to therapeutically target the preservation of endothelial integrity is further emphasized.

In conclusion, the data demonstrate that a chronic deficit in endothelial vasodilator synthesis is sufficient to cause neuropathy in rats. Furthermore, exacerbation of existing endothelial abnormalities by NO inhibition in diabetic rats worsens nerve function. Together this suggests that the endothelial deficits found in diabetic rats and patients could substantially contribute to neuropathy.

Acknowledgements. This work was supported in part by a grant from the British Diabetic Association. KCD and EKM are supported by research studentships from Scotia Pharmaceuticals and ICI Pharmaceuticals, respectively.

\section{References}

1. Low PA, Tuck RR, Takeuchi M (1987) Nerve microenvironment in diabetic neuropathy. In: Dyck PJ, Thomas PK, Asbury AK, Winegrad AI, Porte D (eds) Diabetic neuropathy. Saunders, Philadelphia, pp 266-278

2. Tuck RR, Schmelzer JD, Low PA (1984) Endoneurial blood flow and oxygen tension in the sciatic nerves of rats with experimental diabetic neuropathy. Brain 107: 935-950

3. Cameron NE, Cotter MA, Low PA (1991) Nerve blood flow in early experimental diabetes in rats: relation to conduction deficits. Am J Physiol 261: E1-E8

4. Newrick PG, Wilson AJ, Jakubowski J, Boulton AJM, Ward JD (1986) Sural nerve oxygen tension in diabetes. BMJ 293: 10531054

5. Tesfaye S, Harris N, Jacubowski J, Mody C, Ward J (1990) Impaired blood flow and arterio-venous shunting in human diabetic sural nerve. Diabetic Med 7 [Suppl 2]: 29 A (Abstract)

6. Low PA, Schmelzer JD, Ward KK, Yao JK (1986) Experimental chronic hypoxic neuropathy: relevance to diabetic neuropathy. Am J Physiol 250: E94 E99

7. Masson EA, Church SE, Woodcock AA, Hanley SP, Boulton AJM (1988) Is resistance to ischaemic conduction failure induced by hypoxia? Diabetologia 31:762-765

8. Smith WJ, Diemel LT, Leach RM, Tomlinson DR (1991) Central hypoxaemia in rats provokes neurological defects similar to those seen in diabetes mellitus: evidence for a partial role of endoneurial hypoxia in diabetic neuropathy. Neuroscience $45: 255$ 259

9. Tomlinson KC, Gardiner SM, Hebden RA, Bennett T (1992) Functional consequences of streptozotocin-induced diabetes mellitus, with particular reference to the cardiovascular system. Pharmacol Rev 44: 103-150

10. Cameron NE, Cotter MA (1992) Impaired contraction and relaxation in aorta from streptozotocin-diabetic rats: role of polyol pathway activity. Diabetologia 35: 1011-1019
11. Harris KH, MacLeod KM (1988) Influence of the endothelium on contractile responses of arteries from diabetic rats. Eur J Pharmacol 153:55-64

12. White RP, Carrier GO (1990) Vascular contraction induced by activation of membrane calcium ion channels is enhanced in streptozotocin-diabetes. J Pharmacol Exp Ther 253: 10571062

13. Kamata K, Miyata N, Kasuya Y (1989) Functional changes in potassium channels in aortas from rats with streptozotocin-induced diabetes. Eur J Pharmacol 166: 319-323

14. Horrobin DF (1988) The roles of essential fatty acids in the development of diabetic neuropathy and other complications of diabetes mellitus. Prostoglandins Leukot Essent Fatty Acids 31: 181-197

15. Ward KK, Low PA, Schmelzer JD, Zochodne DW (1989) Prostacyclin and noradrenaline in peripheral nerve of chronic experimental diabetes in rats. Brain 112: 197-208

16. McVeigh GE, Brennan GM, Johnston GD et al. (1992) Impaired endothelium-dependent and independent vasodilation in patients with type 2 (non-insulin-dependent) diabetes mellitus. Diabetologia 35: 771-776

17. Durante W, Sen AK, Sunahara FA (1988) Impairment of endothelium-dependent relaxation in aortae from spontaneously diabetic rats. Br J Pharmacol 94: 463-468

18. Takahashi K, Ghatei MA, Lam H-C, O'Halloran DJ, Bloom SR (1990) Elevated plasma endothelin in patients with diabetes mellitus. Diabetologia 33: 306-310

19. Kiff RJ, Gardiner SM, Compton AM, Bennett T (1991) The effects of endothelin-1 and $\mathrm{N}^{\mathrm{a}}$-nitro-L-arginine methyl ester on regional haemodynamics in conscious rats with streptozotocin-induced diabetes mellitus. Br J Pharmacol 103: 1321-1326

20. Kiff RI, Gardiner SM, Compton AM, Bennett T (1991) Selective impairment of hindquarters vasodilator responses to bradykinin in conscious Wistar rats with streptozotocin-induced diabetes mellitus. Br J Pharmacol 103: 1357-1362

21. Cameron NE, Cotter MA, Robertson S (1989) The effect of aldose reductase inhibition on the pattern of nerve conduction deficits in diabetic rats. OJ Exp Physiol 74:917-926

22. Carrington AL, Ettlinger CB, Calcutt NA, Tomlinson DR (1991) Aldose reductase inhibition with imirestat - effects on impulse conduction and insulin-stimulation of $\mathrm{Na}^{+} / \mathrm{K}^{+}$-adenosine triphosphatase activity in sciatic nerves of streptozotocin-diabetic rats. Diabetologia 34:397-401

23. Cameron NE, Cotter MA, Robertson S (1991) Effects of essential fatty acid supplementation on peripheral nerve and skeletal muscle function and capillarization in streptozotocin diabetic rats. Diabetes 40; 532-539

24. Tomlinson DR, Robinson JP, Compton AM, Keen P (1989) Essential fatty acid treatment - effects on nerve conduction, polyol pathway and axonal transport in streptozotocin diabetic rats. Diabetologia 32: 655-659

25. Cotter MA, Cameron NE, Dines KC, Maxfield EK, Robertson $S, C o x D$ (1992) The effect of evening primrose oil on nerve conduction in diabetic rats depends on product(s) of cyclooxygenase-mediated gamma-linolenic acid metabolism. Diabetic Med 9 [Suppl 1]: A12 (Abstract)

26. Moore PK, al-Swayeh OA, Chong NWS, Evans RA, Gibson A (1990) $\mathrm{L}-\mathrm{N}^{\mathrm{G}}$-nitro arginine (L-NOARG), a novel, L-arginine-reversible inhibitor of endothelium-dependent vasodilation in vitro. Br J Pharmacol 99: 408-412

27. Corbett JA, Tilton RG, Chang K et al. (1992) Aminoguanidine, a novel inhibitor of nitric oxide formation, prevents diabetic vascular dysfunction. Diabetes 41: 552-556

28. Kihara M, Schmelzer JD, Poduslo JF, Curran GL, Nickander KK, Low PA (1991) Aminoguanidine effects on nerve blood flow, vascular permeability, electrophysiology and oxygen free radicals. Proc Natl Acad Sci USA 88: 6107-6111

29. Cameron NE, Cotter MA, Dines KC, Love A (1992) Effects of aminoguanidine on peripheral nerve function and polyol pathway metabolites in streptozotocin-diabetic rats. Diabetologia 35: 946950 
30. Brogden RN, Heel RC, Speight TM, Avery GS (1979) Flurbiprofen: a review of its pharmacological properties and therapeutic use in rheumatic diseases. Drugs 18:417-438

31. Ziada AMAR, Hudlická O, Tyler KR, Wright AJA (1984) The effect of long term vasodilation on capillary growth and performance in rabbit heart and skeletal muscle. Cardiovase Res 18: $724-732$

32. Seneviratne KN, Peiris OA (1969) The effects of hypoxia on the excitability of the isolated peripheral nerves of alloxan-diabetic rats. J Neurol Neurosurg Psychiat 32: 462-469

33. Vane JR, Änggåd EA, Botting RM (1990) Regulatory functions of the vascular endothelium. New Engl J Med 323:27-36

34. Peiper GM, Gross GJ (1988) Oxygen free radicals abolish endothelium-dependent relaxation in diabetic rat aorta. Am J Physiol 255: H825-H833

35. Taylor PD, McCarthy AL, Thomas CR, Poston L (1992) Endothelium-dependent relaxation and noradrenaline sensitivity in mesenteric resistance arteries of streptozotocin-induced diabetic rats. Br J Pharmacol 107:393-397

36. Hill MA, Larkins RG (1989) Altered microvascular reactivity in streptozotocin-induced diabetes in rats. Am J Physiol 257: H1438-H1445

37. Dines KC, Cotter MA, Cameron NE (1992) Treatment with the prostacyclin analogue iloprost reverses reduced nerve conduction in streptozotocin-diabetic rats. Diabetic Med 9 [Suppl 2]: p 60 (Abstract)

38. Cameron NE, Cotter MA, Ferguson K, Robertson S, Radcliffe MA (1991) Effects of chronic $\alpha$-adrenergic receptor blockade on peripheral nerve conduction, hypoxic resistance, polyols, $\mathrm{Na}-\mathrm{K}$ ATPase activity and vascular supply in streptozotocin-diabetic rats. Diabetes 40: 1652-1658

39. Cameron NE, Cotter MA (1992) Dissociation between biochemical and functional effects of the aldose reductase inhibitor ponalrestat on peripheral nerve in diabetic rats. $\mathrm{Br} J$ Pharmacol 107: 939-944

40. Davidson WS, Murphy DG (1985) Aldehyde reductases and their involvement in muscular dystrophy. In: Flynn TG, Weiner $\mathrm{H}$ (eds) Enzymology of carbonyl metabolism 2: aldehyde dehydrogenase, aldo-keto reductase, and alcohol dehydrogenase. AR Liss Inc, New York, pp 251-263

41. Cameron NE, Cotter MA, Robertson S (1992) Angiotensin converting enzyme inhibition prevents the development of muscle and nerve dysfunction and stimulates angiogenesis in streptozotocin-diabetic rats. Diabetologia 35: 12-18

42. Parry GJ, Kohzu H (1989) Studies of resistance to ischemic nerve conduction failure in normal and diabetic rats. J Neurol Sci 93: $61-67$
43. Robertson S, Cameron NE, Cotter MA (1992) The effect of the calcium antagonist nifedipine on peripheral nerve function in streptozotocin-diabetic rats. Diabetologia 35: 1113-1117

44. Kappelle AC, Bravenboer B, Traber J, Erkelens DW, Gispen WH (1992) The $\mathrm{Ca}^{2+}$ antagonist nimodipine counteracts the onset of an experimental neuropathy in streptozotocin induced, diabetic rats. Neurosci Res Commun 10: 95-104

45. Maxfield EK, Cameron NE, Cotter MA (1992) Angiotensin II receptor blockade improves nerve function in streptozotocindiabetic rats. Diabetic Med 9 [Suppl 2]: P59 (Abstract)

46. Simpson LO (1988) Altered blood rheology in the pathogenesis of diabetic and other neuropathies. Muscle Nerve 11: 725-744

47. Maiello M, Boeri D, Podesta Fet al. (1992) Increased expression of tissue plasminogen activator and its inhibitor and reduced fibrinolytic potential of human endothelial cells cultured in elevated glucose. Diabetes 41: 1009-1015

48. Gardiner SM, Compton AM, Bennett T, Palmer RMJ, Moncada $S$ (1990) Regional haemodynamic changes during oral ingestion of $\mathrm{N}^{\mathrm{G}}$-monomethyl-L-arginine or $\mathrm{N}^{\mathrm{G}}$-nitro-L-arginine methyl ester in conscious Brattleboro rats. Br J Pharmacol 101: 10-12

49. Monafo WM, Eliasson SG, Shimazaki S, Sugimoto H (1988) Regional blood flow in resting and stimulated sciatic nerve of diabetic rats. Exp Neurol 99: 607-614

50. Bucala R, Tracey KJ, Cerami A (1991) Advanced glycosylation products quench nitric oxide and mediate defective endothelium-dependent vasodilation in experimental diabetes. J Clin Invest $87: 432-438$

51. Ram Z, Sadeh M, Walden R, Adar R (1991) Vascular insufficiency quantitatively aggravates diabetic neuropathy. Arch Neurol 48: 1239-1242

52. Zochodne DW, Huang Z, Ward K, Low PA (1990) Guanethidine adrenergic sympathectomy augments endoneurial perfusion and lowers endoneurial microvascular resistance. Brain Res 519: $112-117$

53. Hudlická O, Tyler KR (1986) Angiogenesis: the growth of the vascular system. Academic Press, New York

Received: 4December 1992

and in revised form: 22 February 1993

Dr.N.E.Cameron

Department of Biomedical Sciences

University of Aberdeen

Marischal College

Aberdeen AB9 1 AS

Scotland, UK 